\title{
NEGOSIASI PEMBELI DAN PEDAGANG DI PASAR TRADISIONAL GEUDONG (Studi pada Penjual Pakaian Dewasa di Kecamatan Samudera Kabupaten Aceh Utara Periode Bulan Januari- Mei 2021)
}

\author{
Subhani,S.Sos.,M.Si ${ }^{1}$, Harinawati,S.Sos.,MA ${ }^{2,}$ Muhammad Ali A.Ag.,M.Si ${ }^{3}$ dan \\ Maulidayanti,M.I.Kom ${ }^{4}$ \\ ${ }^{1,2 \& 3}$ Dosen Program Studi Ilmu Komunikasi Universitas Malikussaleh \\ Email: subhani@unimal.ac.id \\ 4. Sarjana Ilmu Komunikasi Universitas Malikussaleh
}

\begin{abstract}
ABSTRAK
Penelitian ini berjudul "Negosiasi Pembeli Dengan Pedagang di Pasar Tradisional Geudong (Studi pada Penjual Pakaian Dewasa di Kecamatan Samudera Kabupaten Aceh Utara)". Tujuan penelitian ini adalah untuk mengetahui Untuk mengetahui bagaimana negosiasi antara penjual dan pembeli melakukan transaksi jual beli di toko pakaian dewasa pada pasar tradisional Geudong Kecamatan Samudera Kabupaten Aceh Utara. Teori yang digunakan adala perilaku negosiasi. Penelitian ini menggunakan pendekatan kualitatif deskriptif. Data yang dikumpulkan dengan tiga teknik yaitu observasi, wawancara dan dokumentasi. Instrumen dalam penelitian ini adalah 10 orang. Hasil Penelitian menujukan bahwa negosiasi antara pedagang dan pembeli dalam menentukan kesepakatan harga ketika tawar-menawar barang dan penjelasan terhadap barang yang diperdagangkan, adanya timbal balik yang terjadi ketika melakukan tawar menawar antara kedua pihak karena pedagang pakaian pasar tradisional Kecamatan Samudera identik dengan tawar-menawar, serta penjelasan yang diberikan oleh pedagang akan membuat pembeli kembali bertanya ataupun memberi respon terhadap penjelasan pedagang.
\end{abstract}

Kata Kunci : Negosiasi, Teori Perilaku Negosiasi, pembeli dan pedagang Pasar Tradisional

\section{Latar Belakang Masalah}

Negosiasi pada essensi masyarakat tidak terlepas dari kebutuhan akan kesesuaian yang ingin diperoleh dari pengorbanan yang dilakukan dengan manfaat hasil yang diperoleh sehingga secara sadar maupun tidak, kegiatan negosiasi senantiasa melekat dalam kehidupan kita sehari-hari (Lewicki. 2012: 35). Dalam suatu tatanan masyarakat, sebuah negosisasi terjadi dalam platform komunikasi interpersonal yang merupakan suatu bentuk komunikasi yang dibangun oleh seseorang dengan orang lain dalam suatu masyarakat tertentu untuk suatu tujuan tertentu.

Komunikasi interpersonal juga sering terjadi pada proses negosiasi antara pembeli dan penjual di pasar tradisional biasa dan sering sekali proses ini terjadi pada toko pakaian dewasa terlebih dipasar tradisional yang sangat sering terjadi. Praktik negosisasi paling 
mudah ditemui saat sedang berbelanja di pasar tradisional. Berbeda dari pasar modern (swalayan) yang sistem pelayanannya mandiri dengan harga barang yang telah ditetapkan oleh pemilik swalayan sehingga barang tak dapat ditawar, di pasar tradisional para penjual dan pembeli bertemu secara langsung untuk melakukan transaksi jual beli terhadap suatu barang yang harganya masih bisa ditawar.

Dalam proses interaksi jual beli, keterampilan berkomunikasi adalah sebuah penunjang. Pedagang dituntut agar menjadi orang yang fleksibel dan mampu berkomunikasi serta bernegosiasi dengan baik apabila tidak ingin dagangannya tidak laku. Berbeda dengan pedagang yang bernegosiasi agar memperoleh laba (tidak rugi), bagi seorang pembeli, memiliki keterampilan juga penting, sebab melakukan negosisasi harga dengan menawar barang di pasar mesti dilakukan untuk mengupayakan suatu tindakan penghematan dengan meminimkan pengeluaran. Keriuhan tawar-menawar di Pasar Tradisional Geudong ini terus menjadi ciri dan karakter pasar ini.

Pengunjung yang kemudian tertarik untuk membeli bahkan harus mencoba keahlian tawar-menawar yang dimiliki. Di pasar ini tawar-menawar sudah menjadi suatu keahlian yang memang dibutuhkan agar mendapatkan harga miring. Tawar-menawar adalah suatu proses tradisional dalam sistem jual-beli pada sebuah pasar dalam mekanisme perdagangan. Pasar menjadi tempat yang sangat strategis dalam praktik jualbeli dengan tawar- menawar, tentunya yang dimaksud adalah pasar tradisional. Proses jual-beli yang sedang terjadi (jika pengunjung berminat) pastilah akan masuk pada tahap tawar-menawar. Tentu pada tahap ini ada keunikan-keunikan tertentu yang melibatkan komunikasi verbal dan nonverbal di setiap prosesnya.

Fenomena yang terjadi adalah kondisi negosiasi sepihak yang hanya diarahkan oleh si pembeli tanpa meminta pihak penjual untuk memberikan pendapatnya sehingga berdampak pada persetujuan harga sepihak yang memaksa penjual untuk menyetujui negosiasi harga yang diinginkan oleh pembeli sehingga proses ini mengakibatkan negosisasi yang terjadi dapat merugikan penjual karena penjual tidak memperoleh tingkat keuntungan sesuai yang diharapkan sehingga proses negosiasi yang terjadi tidak menjadi fasilitas bagi kedua pihak untuk memperoleh persetujuan tanpa ada pihak yang dirugikan.

\section{Rumusan Masalah}


Adapun rumusan masalah yang penulis tetapkan untuk penelitian ini adalah: Bagaimana negosiasi antara pembeli dan pedagang melakukan transaksi jual beli di toko pakaian dewasa pada pasar tradisional Geudong Kecamatan Samudera Kabupaten Aceh Utara

\section{Landasan Teori}

\section{Teori Perilaku Negosiasi}

Kehidupan manusia kerap dihadapkan pada berbagai pilihan guna memenuhi kebutuhan hidupnya. Ada banyak faktor dan alasan yang mendorong manusia untuk melakukan suatu pembelian. Menurut Sangadji (2013: 9) perilaku konsumen adalah tindakan yang dilakukan konsumen untuk mencapai dan memenuhi kebutuhannya baik untuk menggunakan, mengonsumsi maupun menghabiskan barang dan jasa, termasuk di dalamnya proses keputusan yang mendahului dan menyusul. Teori tingkah laku (Behaviorial theory) merupakan teori yang berfokus pada perilaku ataupun tingkah laku yang dilakukan oleh para negosiator sebagai akibat dari stimulus yang menekankan pentingnya kebutuhan. Jones (2016: 25).

Menyebutkan bila teori perilaku merupakan teori yang menekankan pentingnya kebutuhan untuk memusatkan perhatian pada kehidupan sosial tingkat mikro, cara individu berinteraksi satu sama lain dalam kondisi hubungan sosial secara individual. Pada dasarnya, teori perilaku merupakan kajian psikologi yang diaplikasikan melalui teori belajar dalam menyelesaikan konflik. Dibanding teori lain, penggunaan teori ini lebih mempertimbangkan penyelesaikan masalah dengan melihat proses yang ada. Hal ini disebabkan oleh oleh adanya pertimbangan dalam memperhatikan peranan perilaku dan pemikiran untuk menyelesaikan konflik tersebut. Menurut Mcguire (2004:91), beberapa asumsi dasar dari teori perilaku negosiasi adalah sebagai berikut: 1 . Negosiasi adalah sebuah alat atau instrumen yang digunakan untuk mencapai beberapa tujuan akhir yang penting. Beberapa fitur dan proses negosiasi digambarkan dan dievaluasi dalam kaitannya dengan beberapa hasil yang diinginkan terlepas dari proses yang berbeda. 2 . Negosiasi adalah proses menghasilkan perubahan yang mendasar dalam suatu perselisihan. Perubahan itu mungkin menghalagi berbagai pihak untuk memahami konflik, hubungan, situasi atau diri mereka sendiri. Perubahan dapat terjadi pada tingkatan isu, aktor atau pemain, peraturan, struktur dan konteks. 3. Individu adalah 
kekuatan pendorong dalam negosiasi. Individu berperan dalam membuat berbagai pilihan strategis, menangani hubungan, mengelola wajah, dan menggunakan kekuasaan.

menyebutkan bila teori perilaku merupakan teori yang menekankan pentingnya kebutuhan untuk memusatkan perhatian pada kehidupan sosial tingkat mikro, cara individu berinteraksi satu sama lain dalam kondisi hubungan sosial secara individual. Pada dasarnya, teori perilaku merupakan kajian psikologi yang diaplikasikan melalui teori belajar dalam menyelesaikan konflik. Dibanding teori lain, penggunaan teori ini lebih mempertimbangkan penyelesaikan masalah dengan melihat proses yang ada. Hal ini disebabkan oleh oleh adanya pertimbangan dalam memperhatikan peranan perilaku dan pemikiran untuk menyelesaikan konflik tersebut.

Menurut Mcguire (2004:91), beberapa asumsi dasar dari teori perilaku negosiasi adalah sebagai berikut: 1 . Negosiasi adalah sebuah alat atau instrumen yang digunakan untuk mencapai beberapa tujuan akhir yang penting. Beberapa fitur dan proses negosiasi digambarkan dan dievaluasi dalam kaitannya dengan beberapa hasil yang diinginkan terlepas dari proses yang berbeda. 2. Negosiasi adalah proses menghasilkan perubahan yang mendasar dalam suatu perselisihan. Perubahan itu mungkin menghalagi berbagai pihak untuk memahami konflik, hubungan, situasi atau diri mereka sendiri. Perubahan dapat terjadi pada tingkatan isu, aktor atau pemain, peraturan, struktur dan konteks. 3 . Individu adalah kekuatan pendorong dalam negosiasi. Individu berperan dalam membuat berbagai pilihan strategis, menangani hubungan, mengelola wajah, dan menggunakan kekuasaan.

\section{Metode Penelitian}

Pada penelitian ini, jenis penelitian yang penulis gunakan adalah penelitian lapangan yang bersifat kualitatif. Bogdan dan Taylor (dalam Moelong, 1994:3) mengartikan penelitian kualitatif sebagai suatu bentuk penelitian yang menghasilkan data deskriptif mengenai kata-kata lisan dan juga tulisan, serta setiap tingkah laku yang dapat diamati dari orang-orang yang diteliti. Dalam penelitian ini digunakan pendekatan kualitatif dengan metode analisis deskriptif kualitatif dimana hasil penelitian yang disajikan dalam bertuk uraian penjelasan berupa kata-kata yang digunakan untuk menjawab pertanyaan penelitian. 


\section{Hasil Penelitian dan Pembahasan}

\section{Gambaran Umum Kecamatan Samudera}

Geudong merupakan ibukota Kecamatan Samudera. Kecamatan Samudera berbatasan dengan Kecamatan Syamtalira Aron, Tanah Pasir dan Nibong di sebelah utara, lalu disebelah barat berbatas dengan Kecamatan Syamtalira Bayu, disebelah selatan berbatasan dengan Kecamatan Meurah Mulia serta sebelah utara berbatasan dengan Selat Malaka. Kecamatan ini memiliki wilayah sekitar 43,28 / 4.328 Ha. Letak ibu kota kecamatan Samudera yaitu Geudong sangat strategis untuk usaha perdagangan, apalagi ketersediaan barang mulai dari kebutuhan pokok rumah tangga, barang material bangunan, perabotan, pakaian, apotik, barang elktronik dan masih banyak lainnya. Dengan adanya semua barang- tersebut masayarakat lebih mudah mencari perlengkapan di satu area.

Keberadaan masing-masing pedagang saling menguntungkan satu sama lainnya. Di Kecamatan Samudera terdapat 40 desa yang terdiri dari 33 (tiga puluh tiga) desa yang berada didataran dan 7 (tujuh) desa berada dekat pantai. Dari 40 (empat puluh) desa tersebut dibagi menjadi 3 (tiga) kemukiman yaitu Madan, Langgahan dan Blang Mee. Tahun 2019 penduduk Kecamatan Samudera berjumlah 28.688 jiwa. Dari 28.688 jiwa, yang berjenis laki- laki berjumlah 14.229 dan yang berjenis kelamin perempuan berjumlah 14.459 jiwa.

\section{Negosiasi Antara Pedagang dan Pembeli}

Pasar merupakan pasar tradisional yang telah lama berdiri dan merupakan salah satu pasar tradisional yang cukup terkenal di Kecamatan Samudera. Pasar selalu terlihat ramai di pagi hari hingga akses mobil menuju ke pasar tersebut sangat susah karena pasti akan macet disana karena ada beberapa mobil dan kendaraan yang parkir sembarangan. Sehingga akses untuk keluar masuk jika ramai agak sulit dilalui walaupun dengan berjalan kaki. Penjual di Pasar lebih aktif dalam rangka menawarkan produknya. Penjual di pasar umumnya akan menawarkan dagangannya kepada setiap yang lewat dan yang memenuhi kriteria target produk yang dijual. 1. Game Theory Salah satu penjual Toko Baju Rasyidah (24) memberikan informasi tentang bagaimana cara memasarkan mengenai cara menawarkan barang pada pembeli terkait tentang sikap, metode, dan komunikasi dalam menjual. Berikut adalah hasil dari wawancara tersebut :

“......."Waktu calon pembeli datang langsung tanya apa yang di carinya, pasti saya harus ramah dan sopan supaya pembelinya nyaman. Dalam melakukan 
penjualan kita harus padai menawarkan harga dan barang yang tanpa menarik pembeli " (wawancara, 05 Maret 2021).

Berdasarkan wawancara di atas maka dapat dia anlisis bahwa cara memasarkan barang dangangannya dengan memasang wajah senyum dan menyapa agar pembeli tertarik untuk datang kemudian melihat-lihat dan minat untuk membeli. Tata cara memasarkan produk sangat diperlukan oleh penjual sehingga menarik pembeli dalam membeli. Menurut Musliadi (38) memberikan informasi tentang bagaimana cara cara menawarkan barang pada pembeli terkait tentang sikap, metode, dan komunikasi adalah sebagai berikut: "Saat calon pembeli datang saya menanyakan barang apa yang di cari, tentu saja dengan sikap yang ramah dan berbicara dengan tutur kata yang sopan dan santun agar calon pembeli nyaman dan menawarkan barang yang terbaru dan termurah terkadang calon pembeli tidak semua seleranya baju-baju bermerek sesuai dengan keinginan pembeli, kita harus gesit dalam menawarkan barang dengan harga relatif normalagar menarik minat si pembeli" (wawancara, 05 Maret 2021).

Sikap penjual terhadap pembeli sangat diperlukan bagi seorang penjual. Karena itu salah satu karakteristik penjual untuk menarik pembeli agar tertarik dan mau berbelanja di toko kami sehingga penjualan kami akan meningkat nntinya. Berdasarkan penuturan dari Leni Marlina (22 ) menyatakan hal yang sama tentang tentang sikap, metode, dan komunikasi dalam menjual:

"... Biasanya orang itu membeli barang yang mereka kehendaki berapa, aku bilang harganya kemudian aku jelasi kulitas barangnya. Terus kutawari barang yang lain yang hampir sama tapi beda kualitas. Terus kami melakukan negosiasi." (wawancara, 05 Maret 2021).

Bedasarkan dari wawancara di atas maka dapat disimpulkan bahwa penjual berusaha untuk menarik minat pembeli dengan komunikasi barang terbaru dan warna yang menarik sehingga menarik pembeli untuk datang ke toko.

Pada transaksi perdagangan negosiasi menjadi hal yang dominan. Dalam makna sempitnya negosiasi di sebuah pasar menjadi proses tawar menawar yang menarik. Di satu pihak pedagang pasti memberikan kesempatan dalam proses jual 65 beli untuk melakukan tawar-menawar. Karena tawarmenawar adalah hal penting bagi pasar tradisional. Pasar tradisional pada umumnya diawali oleh aksi penjual yang menawarkan barang dagangannya. Pada tahap ini penjual juga melakukan analisis sederhana tentang latar belakang pengunjung. Melalui pesan nonverbal pengunjung yang bisa dilihat dari 
penampilan pakaian dan juga pembeli sering menangkap pesanverbal yang tidak sengaja diterima oleh indra penjual.

Kecamatan Samudera mengarah pada sektor perdagangan, khususnya penjual pakaian dewasa. Pedagang pakaian merupakan salah satu lahan bisnis yang sangat berkembang saat ini. Hal ini dapat dibuktikan dengan semakin banyaknya toko-toko yang menjual berbagai jenis pakaian. Untuk mendapatkan pelanggan dan keuntungan yang banyak dibutuhkan penjualan yang baik mulai dari segi pelayanan hingga sistem penjualan. Sistem katalog merupakan salah satu pelayanan untuk mempermudah pelanggan dalam memilih barang yang diinginkan. Sektor ini semakin meningkat dari tahun ke tahun. Tingkat permintaan pakaian di Kecamatan Samudera juga terbilang tinggi. Selain itupakaian sangat diminati oleh para pembeli khususnya kaum perempuan yang memiliki berbagai macam jenis model pakaian, salah satunya yang paling terkenal dan laku di pasaran saat ini adalah pakaian berjenis syar’i.

Pedagang menawarkan barang kepada pembeli terjadilah negosiasi dalam tawarmenawar di suatu pasar adalah hal yang dicari oleh penjual serta juga pembeli. Hal ini juga berlaku di Pasar Kecamatan Samuderadi mana terdapat negosiasi jual-beli dan banyak diantara orang yang datang adalah pengunjung dari luar daerah samudera yang awal mulanya hanya melihat-lihat dan membeli produk dengan tidak terencana. 66 Kesepakatan tawar-menawar yang terjadi di Pasar Kecamatan Samudera paling mendasar adalah persoalan soal harga. Hargalah yang umumnya menentukan terjadinya kesepakatan walaupun ada hal lain yang juga bisa menjadi faktor penentu kesepakatan. Selain harga terdapat beberapa hal yang mampu menjadi faktor penentu yang keberadaannya dapat mempengaruhi harga yaitu ketersediaan barang, keadaan pasar, jumlah pembelian, serta keberadaan pemilik. Yang perlu kita ketahui dalam negosiasi tidak akan pernah tercapai kesepakatan kalau sejak awal masing-masing atau salah satu pihak tidak memiliki niat untuk mencapai kesepakatan.

Kesepakatan harus dibangun dari keinginan atau niat dari kedua belah pihak, sehingga kita tidak bertepuk sebelah tangan. Sejak menjadi seorang pedagang pakaian dewasa sudah bertemu dan berinteraksi dengan berbagai macam tipe orang yang berbedabeda. karena pengalamannya yang sudah menerima perbedaan yang ada di Pasar serta dengan pembeli yang mayoritas adalah pembeli pribumi. Selain itu penjual juga menyampaikan pesan kepada pembelinya dengan tutur kata yang sopan dan tidak 
membuat pembeli merasa resah agar transaksi jual- beli dapat berlangsung dengan lancar. Selama pengalamannya dalam berjualan, beliau bertemu dengan pembeli pribumi yang pasti akan selalu melakukan tawar- menawar namun ada juga pembeli pribumi yang tidak melakukan tawar-menawar, artinya langsung membeli dari harga yang diberikan.

Dalam melayani semua pembelinya dengan semangat dan memberikan barang yang apa adanya, jika ada yang bagus, akan ditawarkannya, jika tidak ada, beliau akan menawarkan barang yang ada saja. Agar memberikan sedikit 67 kekhususan dalam pengurangan harga dalam tawar-menawar, selain itu, beliau memperlakukan semua pembeli sama. Penggunaan tanda-tanda seperti menggeleng kepala dan mengangguk tidak terlalu efektif ketika digunakan dalam transaksi jual-beli. Negosiasi adalah bagian dari suatu tindakan ekonomi yang tak lepas dari komunikasi itu sendiri.

Negosiasi memerlukan komunikasi sebagai pembuka jalan guna mendapatkan hasil yang diinginkan. Di dalam ranah ini tawar-menawar berada di bawah negosiasi Tawarmenawar adalah bagian dari suatu tindakan ekonomi yang tak lepas dari komunikasi itu sendiri. Tawar-menawar memerlukan komunikasi sebagai pembuka jalan guna mendapatkan hasil yang diinginkan.. Ketika pembeli memberikan respon positif kepada tawaran penjual maka interaksi akan berlanjut kepada tawarmenawar dengan munculnya pesan- pesan mengenai deskripsi produk secara lengkap bukan hanya jenis-jenis produk saja seperti ketika menawarkan produknya tetapi juga deskripsi lain yang lebih lengkap. Semua deskripsi produk pada akhirnya akan menentukan keberlanjutan kesepakatan tawarmenawar.

Sedangkan hal yang menghambat adalah perkiraan harga yang dimiliki dengan harga dari produk itu sendiri. Ditambah lagi dengan hambatan individu yang berkorelasi dengan tujuan membeli barang dan sikap dari pembeli dan juga penjual. Hambatan lain adalah masalah ketersediaan produk yang dicari yang terkadang kosong atau habis. Jika dilihat dari hambatan komunikasi, tidak ada hambatan yang berarti. Baik hambatan eksternal atau hambatan internal tidak memberikan porsi banyak untuk terjadinya tawarmenawar.

Karakter atau perlikau individu pembeli juga menjadi penghambat 68 tercapainya kesepakatan tawar-menawar. Di Pasar kecamatan Samudera terdapat juga pembeli yang berasal dari desa dengan segala keterbatasan informasi menganai produk yang ada di pasar. Pembeli yang hanya bertanya untuk mengecek harga dan tidak serius atau pembeli 
yang hanya menawar harga terkadang juga menjadi hambatan tersendiri bagi penjual. ketersediaan produk, terkadang produk yang dijual tidak sesuai keinginan dari pembeli. Baik itu jenis, ukuran, warna, bahan dasar dan lain-lain berbeda antara satu pembeli dengan pembeli lain. Banyak keadaan di Pasar trasdisional Kecamatan Samuderadi mana harga tidak menjadi masalah bagi kedua pihak tetapi ternyata produk yang diinginkan tidak tersedia di kios tersebut.

Ketersediaan barang ini juga menjadi faktor penting terjadinya kesepakatan jual beli. Setelah proses penawaran awal berlangsung dan muncul respon positif baik dari pihak yang bertindak sebagai pihak kedua yang memberi umpan balik, maka pihak pertama melanjutkan proses tawar- menawar tersebut. Proses ini akan terjadi jika salah satu pihak tertarik dengan penawaran dari pihak yang menagjukan tawaran. Pertama akan dibahas respon positif pembeli terhadap tawaran penjual. Setiap penjual di Pasar umumnya memiliki cara yang sama dalam merinci produk mereka. Perbedaanya hanya pada jenis produknya, walaupun begitu juga terdapat perbedaan dalam merinci jenis produk.

Cara-cara seperti merayu, memuji, memakai bahasa yang halus dengan nada sopan hingga menjurus ke arah seperti membandingkan harga, berpura-pura marah, sedikit memaksa serta, pura- pura kalah akan dilakukan. Hal di atas juga terjadi di Pasar Kecamatan Samudera dengan aktivitas jual beli yang padat serti persaingan yang ketat. Penjual dan pembeli banyak yang adu argumentasi dan 69 mencoba melakukan tes pada titik mana harga yang cocok dan menguntungkan bagi keduanya. Guna meyakinkan penjual untuk mendapatkan harga yang diinginkan, pembeli di juga menggunakan berbagai cara.Cara-cara yang digunakan beberapa juga terdengar seperti gertakan, dan kebohongan kecil serta trik-trik tertentu.

Ketika pasar berisi penuh dengan orang dan pasti terjadi komunikasi antara satu dengan yang lainnya maka secara tidak langsung percakapan yang terjadi bukan hanya masalah jual-beli. Percakapan lain masalah cuaca, anak-anak, gosipgosip, serta berita terhangat mengenai peristiwa di negeri ini pun juga menjadi bahan obrolan. Baik itu antar penjual sendiri maupun dengan pembeli. Percakapan-percakapan ini juga dimanfaatkan oleh penjual untuk lebih dekat dengan pembeli dan bisa juga untuk trik agar lebih mudah terjadi kesepakatan. Beberapa alasan yang digunakan oleh penjual ketika melakukan percakapan mengenai hal lain di luar proses tawar-menawar adalah agar akrab, untuk 
memudahkan transaksi, mencairkan suasana. Percakapan yang terjadi antara penjual dan pembeli di Pasar juga banyak kalimat humor untuk sekedar mencairkan suasana dan untuk bercanda.

Berdasarkan pengamatan peneliti, merupakan pedagang yang sabar dalam menghadapi pembeli yang memiliki persepsi yang berbeda dengannya karena beliau tahu tidak bisa memaksakan pikiran yang sama dengan pembeli karena setiap pembeli berbeda-beda namun tetap sabar dalam memberikan penjelasan kepada pembelinya agar pembeli juga mengerti apa yang dijual oleh setiap pedagang pastinya memiliki satu atau dua perbedaan. Melihat karakteristik setiap pembeli pribumi penting karena ada beberapa pembelinya yang tidak melakukan 70 tawar-menawar, namun tidak sedikit yang melakukan tawar- menawar karena memang hal yang lumrah untuk melakukan tawarmenawar di pasar tradisional.

Kesepakatan dalam tawar-menawar di suatu pasar adalah hal yang dicari oleh penjual serta juga pembeli. Hal ini juga berlaku di Pasar Kecamatan terdapat interaksi jual-beli dan banyak diantara orang yang datang adalah pembeli yang awal mulanya hanya melihat-lihat dan membeli produk dengan tidak terencana. Tidak bisa dipungkiri, kesepakatan tawar-menawar yang terjadi di PasaKecamatan Samudera paling mendasar adalah persoalan soal harga. Hargalah yang umumnya menentukan terjadinya kesepakatan walaupun ada hal lain yang juga bisa menjadi faktor penentu kesepakatan. Selain harga terdapat beberapa hal yang mampu menjadi faktor penentu yang keberadaannya dapat mempengaruhi harga yaitu ketersediaan barang, keadaan pasar, jumlah pembelian, serta keberadaan pemilik. Dalam proses tawar-menawar sering juga terjadi kegagalan karena penjual dan pembeli tidak mencapai titik temu. Kegagalan yang terjadi banyak didasarkan ketidakcocokan harga serta ketersediaan barang. Ketidak kcocokan harga menjadi kendala utama dalam tawar-menawar disamping produk yang dicari tidak ada serta penjual lain lebih murah dalam menawarkan produk dengan jenis yang serupa. Pembeli kebanyakan tidak akan membeli jika harga produk tersebut tidak sesuai dengan perkiraannya atau melebihi jauh dari perkiraannya. Hambatan komunikasi atau yang juga dikenal sebagai communication barrier adalah segala sesuatu yang menjadi penghalang untuk terjadinya komunikasi yang efektif.

Hambatan komunikasi dalam komunikasi mempunyai bentuk seperti sebuah gunung es yang terbenam di dalam air. Di mana hambatan 71 komunikasi yang ada 
terbagi dua menjadi yang di atas air dan di bawah air. Faktor-faktor hambatan komunikasi antarbudaya yang berada di bawah air adalah faktor-faktor yang membentuk perilaku atau sikap seseorang, hambatan semacam ini cukup sulit untuk dilihat atau diperhatikan. Banyak cara yang digunakan penjual dan pembeli untuk mengakhiri proses tawarmenawar. Mulai dengan cara yang halus hingga cara yang terkesan kasar dengan kalimatkalimat tertentu dan nada-nada tertentu pula. Penjual di Pasar Kecamatan Samudera jika mereka sudah memberikan harga pas maka harga tersebut akan jarang diturunkan kembali kecuali jika pembeli.

Penjual walaupun menolak penawaran pembeli umumnya masih akan sopan dan mereka akan tetap mencoba merayu pembeli. penjual akan tatap santun dan bahkan saking santunnya penjual akan sangat rendah diri dan masih menawarkan sopan santun. Perilaku dari pedagang yang sangat ingin barang dagangan laku dengan harga yang sesuai dengan kualitas barang, sementara pembeli juga sangat menginginkan barang tersebut dibeli. Diantaranya keduanya terjalin suatu saling butuh sehingga terjadilah proses tawar menawar atau bernegosiasi untuk mendapatkan suatu hasil yang mereka inginkan. Dalam menetukan harga penjual pun harus mempertimbangkan beberapa aspek terlebih dahulu. Perilaku pembeli terkadang sangat menampakkan suka terhadap suatu barang, dengan jelas pedagang bisa melihat itu dan mengambil kesempatan dengan menetukan harga seolah-olah tidak bisa ditawar lagi dengan alasan seperti kualitas barang yang sangat bagus, tidak ambil keuntungan banyak dan lainnya.

\section{Kesimpulan}

Negosiasi antara pedagang dan pembeli dalam menentukan kesepakatan harga ketika tawar-menawar barang dan penjelasan terhadap barang yang diperdagangkan, adanya timbal balik yang terjadi ketika melakukan tawar-menawar antara kedua pihak karena pedagang pakaian pasar tradisional Kecamatan Samudera identik dengan tawarmenawar, serta penjelasan yang diberikan oleh pedagang akan membuat pembeli kembali bertanya ataupun memberi respon terhadap penjelasan pedagang.

\section{DAFTAR PUSTAKA}

Abdulsyani, 2012, Sosiologi: Skematika, Teori dan Terapan, Jakarta: Rajawali Pers.

Afrizal, 2014, Metode Penelitian Kualitatif: Upaya Mendukung Penggunaan Penelitian Kualitatif Dalam Berbagai Disiplin IlmuI, Jakarta: Rajawali Pers.

Agus, M. Hardjana, 2003, Komunikasi Intrapersonal \& Komunikasi Interpersonal, Yogyakarta: Penerbit Kanisius. 
Anggrina, Dina Rini, 2013, Model Komunikasi Dalam Proses Negosiasi (Studi Deskriptif Kualitatif Tentang Model Komunikasi Dalam Proses Negosiasi Antara BPLS Dengan Masyarakat Terdampak Dalam Menyelesaikan Ganti Rugi Lapindo), Program Studi Ilmu Komunikasi Fakultas Ilmu Sosial dan Ilmu Politik Universitas Pembangunan Nasional.

Anwar, Saifuddin, 1998, Metodelogi Penelitian, Yogyakarta: Pustaka Pelajar.

AW, Suranto, 2011, Komunikasi Interpersonal, Yogyakarta: Graha Ilmu.

Barge (2009). Self Confidence and Social Interactions. The Quarterly Journal of Economics. Princeton University. Vol. 117, Section 4 Page 871

Birowo, M. Antonius, 2004, Penelitian Komunikasi, Yogyakarta: Gitanyali.

Boy, La, 2017, Pola-Pola Komunikasi Dalam Negosiasi Antara Penjual dan Pembeli di Pasar Wakuru, Jurnal Bastra, Vol. 1.

Bungin, Burhan, 2003, Analisisi Data Penelitian Kualitatif. Jakarta: PT. Raja Grafindo Persada.

Cangara, Hafied, 2004, Pengantar Ilmu Komunikasi, Jakarta: Raja Grafindo Persada.

Effendy, Onong Uchjana, 2006, Ilmu Komunikasi Teori dan Praktik, Bandung: PT. Remaja Rosdakarya.

Fitriana, Intan , 2017, Strategi Negosiasi Untuk Meningkatkan Publisitas Syariah Hotel Sole Sebagai Destinasi Wisata Halal, Program Studi Ilmu Komunikasi Fakultas Ilmu Sosial dan Humaniora UIN Sunan Kalijaga Yogyakarta.

Heron (2009). Helping Students Develop An Understanding Of Archimedes' Principle. I. Research on student understanding. American Journal of Physics, 71(11), 11781187.

Hidayat, Dasrun, 2012, Komunikasi Antarpribadi dan Medianya, Yogyakarta: Graha Ilmu. Idrus, Muhammad, 2009, Metode Penelitian Ilmu Sosial: Pendekatan Kualitatif dan Kuantitatif, Yogyakarta: Erlangga.

Iskandar, 2009, Metodelogi Penelitian Kualitatif: Aplikasi Untuk Penelitian Pendidikan, Hukum, Ekonomi dan Manajemen, Sosial Humaniora, Politik, Agama, dan Filsafat. Jakarta: Gaung Persada.

Jones, Pip, dkk., 2016, Pengantar Teori-Teori Sosial, Jakarta: Yayasan Pustaka Obor Indonesia.

Krisyantono, Rachmat, 2009, Teknik Praktik Riset Komunikasi, Malang: prenada Media Group.

Lewicky, Roy J., Bruce Barry dan David M. Sanders, 2012, Negosiasi, Terjemahan oleh M. Jusuf Hamdani, Jakarta: Salemba Humanika.

Lexy J, Moleong, 1994, Metode Penelitian Kualitatif, Bandung: PT Remaja Rosdakarya

Mc Guire (2004). An Important Life Skill. The Pharmaceutical Journal. Vol.273. (2325) 
Mukhtar, 2013, Metode Praktis Penelitian Kualitatif Deskriptif. Jakarta: Referensi.

Mulyana, Dedi, 2010, Komuunikasi Efektif: Suatu PendekatanLintas Budaya. Bandung: Rosda. Nawawi,

Hadari, 2001, Metodelogi Bidang Sosial, Yogyakarta: Gajah Mada University Press.

Pohan, Syarifuddin, dkk., 2012, Buku Pedoman Penulisan Skripsi dan Proposal penelitian, Medan: Grafindo.

Pujileksono, Sugeng, 2015, Metodelogi Penelitian Komunikasi Kualitatif, Malang: Intrans Publishing.

Purwanto, Djoko, 2006, Komunikasi Bisnis: Edisi Ke-3, Jakarta, Erlangga.

Rahmat, Jalaludin, 2005, Psikologi Komunikasi, Bandung: Remaja Rosdakarya 